Miguel, S., Bongiovani, P. C., Gómez, N. D., \& Bueno-de-la-Fuente, G. (2013). Prospect for Development of Open Access in Argentina. The Journal of Academic Librarianship,39(1), 1-2. http://dx.doi.org/10.1016/j.acalib.2012.10.002

\title{
Prospect for development of Open Access in Argentina
}

\author{
Sandra Miguel*, Paola C. Bongiovani**, Nancy D. Gómez***, Gema Bueno-de-la-
}

\section{Fuente***}

This perspective article presents an overview of the Open Access movement in Argentina, from a global and regional (Latin American) context. The article describes the evolution and current state of initiatives by examining two principal approaches to Open Access in Argentina: golden and green roads. The article will then turn its attention to: the support that Open Access receives from governmental sources; collaboration with international projects; and the perspective of Argentine authors regarding Open Access and self-archiving. It concludes with a reflection on the outlook, the main barriers and opportunities for Open Access in Argentina.

*Instituto de Investigaciones en Humanidades y Ciencias Sociales y Departamento de Bibliotecología, Facultad de Humanidades y Ciencias de la Educación, Universidad Nacional de La Plata, Argentina Grupo de Investigación SCImago, CSIC, Madrid, Spain $<$ sandra@fcnym.unlp.edu.ar>, $<$ http://www.scimago.es>;

** Centro Internacional Franco Argentino de Ciencias de la Información y de Sistemas (CIFASIS), Universidad Nacional de Rosario, Argentina <pbongio@unr.edu.ar>;

***Departamento de Biblioteconomía y Documentación, Facultad de Humanidades, Comunicación y <ndgomez@bib.uc3m.es>; <gbueno@bib.uc3m.es>

\section{Introduction}

In a world where access to information is fundamental for the economic and social growth of a country, the Open Access (OA) movement is establishing itself as a model for publishing scientific and academic literature which offers open and free access to publications through the internet $^{1}$. The two best developed approaches are: the golden road of publication in journals which are $\mathrm{OA}$; and the green road, self-archiving on the internet of articles published in traditional subscription-based journals. Selfarchiving occurs before (pre-print) or after (post-print) the publication of the journal, depending largely on the editors' copyright rules.

It is not clear which approach will predominate in the near future. Harnad and others $^{2}$ suggest that providing a mandate for the green road is the only way to reach $100 \% \mathrm{OA}$, as it does not 
require a substantive change in the system of scientific publishing. Suber ${ }^{3}$ suggests the two approaches should complement one another: publishing opportunities on the golden road are limited to the $30 \%$ of journals published as OA, while some people take advantage of the green road's benefits of a low-cost and rapid transition to publications being freely accessible online.

Recent international studies show there is still a low proportion of articles freely available. A study of articles published in journals included in the Web of Science shows only $23.4 \%$ are freely available on the web: $21 \%$ of these through the green road, $2.4 \%$ through the golden road ${ }^{4}$. Moreover it is impossible to generalize. The two approaches show levels of development which vary according to both the field and geography ${ }^{5}$. In the latter case the policies of governments and of research funders have significant influence ${ }^{78}$.

The new modes of publication and diffusion of research outcomes, along with their political, economic, social and cultural impact is the subject of many discussions. Not only do these occur within the scientific community, but also in the publishing market and among research funding agencies and national governments. Within this context the present work offers an overview of the current state and outlook for development of the OA movement in Argentina.

\section{Current State and Principal Trends of Open Access in Argentina}

In Argentina, both the green and golden road approaches to OA have shown notable growth in the last few years. On the golden road, 92 Argentine journals are included in SciELO - Scientific Electronic Library Online ${ }^{9}, 42$ in RedALyC (Red de Revistas Científicas de América Latina y el Caribe, España y Portugal) ${ }^{10}$ and 126 in DOAJ (Directory of Open Access Journals) ${ }^{11}$. Although these figures represent a small fraction of global Open Access journals, the growth over the last 5 years - $67 \%$ in DOAJ and $114 \%$ in SciELO $^{12}$ - indicates a significant progress of this approach in Argentina.

The number of repositories used for green road publication has also grown notably in the last few years. According to ROAR (Registry of Open Access Repositories), Argentina went from two repositories in $2007^{13}$ to 24 in $2012^{14}$. In OpenDoar, ${ }^{15}$ the Argentine presence in the region is $11 \%$, and in CSIC's Ranking Web de Repositorios Mundiales ${ }^{16}$ it is the second-most represented country in Latin America, behind Brazil. 
The Ministry of Science and Technology (MINCyT) plays an active role in the development of the Open Access movement in Argentina. The Ministry created a National System of Digital Repositories and then lobbied for government regulation promoting the creation of repositories and self-archiving of scientific results from publicly funded research $^{17}$. By May 2012, a law supporting this initiative was approved by the National Chamber of Deputies ${ }^{18}$.

In addition, MINCyT and the National Interuniversity Council (CIN) allocated a specific line of its funding for research to the development of digital institutional repositories. In 2012, five projects were underway across Argentina with participation from approximately $60 \%$ of the country's universities, and leading role is being played by academic libraries.

Recent studies of communication practices among Argentine researchers show a progressive outlook. Of articles published in 2008-2010 in journals listed in SCOPUS, $27 \%$ are OA through golden road publication, and $43 \%$ could be selfarchived in green road Open Access repositories. The proportion varies between disciplines: Social Sciences, Humanities and Medicine show a preference for the golden road, while the green road predominates in Physics, Astronomy, Agriculture and Biological Sciences ${ }^{19}$.

Argentine researchers hold a very favorable opinion of OA. The survey carried out in 2010 as part of the SOAP (Study of Open Access Publishing) project $^{20}$ shows that a high proportion (71\%) of Argentine researchers in diverse subject areas are aware of OA journals in their field of expertise, and are in favor of the OA movement, because they believe that it benefits the scientific community. 21

\section{Conclusions}

Argentina has a great potential to offer a significant proportion of its scientific journal publication in OA, but this is far from the reality yet. The green road is promoted through national policies creating a mandate for self-archiving of the national scientific and technological production at institutional repositories and providing funding to that end. The golden road, through the inclusion and indexing of Argentine scientific journals is leading regional OA portals such as SciELO and RedALyC.

Which approach to OA will be more successful in Argentina? Only time will tell. It will depend on the development of the national mandate and its success and 
on the progress of OA globally and its repercussions in the international and national scientific communities. While government promotion and the attitude of researchers suggest a favorable future for OA in Argentina, a great deal of work remains to ensure democratization of and free global access to scientific knowledge. In this effort, the role of libraries and librarians will continue to be fundamental ${ }^{22}$.

\section{References}

${ }^{1}$ Budapest Open Access Initiative, Open Society Institute, Budapest (2001). http://www.soros.org/openaccess/read.s html

2 Stevan Harnad, Tim Brody, François Vallieres, Leslie Carr, Steve Hitchcock, Yves Gingras, Charles Oppenheim, Chawki Hajjem, Eberhardt Hilf, "The access/impact problem and the green and gold roads to open access: An update," Serials Review 34, no. 1 (2008), pp. 36-40, Available: ,

(September 9, 2012)

3 Peter Suber, "Ensuring open access for publicly funded research, " $B M J$ (Clinical Research Ed.), 345 (2012), Available: doi: 10.1136/bmj.e5184, (September 9, 2012).
${ }^{4}$ Yassine Gargouri, Vincent Larivière, Yves Gingras, Les Carr, Stevan Harnad, Green and Gold Open Access Percentages and Growth, by Discipline, (2012), Available: http://arxiv.org/abs/1206.3664, (September 9, 2012).

5 Bo-Christer Björk, Patrik Welling, Mikael Laakso, Peter Majlender, Turid Hedlund, Guðni Guðnason, “Open access to the scientific journal literature: Situation 2009," PLoS ONE, 5, no. 6 (2010), Available: doi:10.1371/journal.pone.0011273, (September 9, 2012).

${ }^{6}$ Sandra Miguel, Zaida ChinchillaRodríguez, Félix de Moya-Anegón, "Open access and Scopus: A new approach to scientific visibility from the standpoint of access," Journal of the American Society for Information Science and Technology, 62, no. 6 (2011), pp. 1130-1145.

${ }^{7}$ Federal Research Public Access Act (FRPAA) http://www.arl.org/sparc/advocacy/frpaa /index.shtml

${ }^{8}$ Peter Suber, "Tectonic movements toward OA in the UK and Europe", SPARC Open Access Newsletter (September, 2012), Available: 
http://www.earlham.edu/ peters/fos/ne wsletter/09-02-12.htm\#uk-ec,

(September 9, 2012).

9 Scientific Electronic Library Online (SciELO) http://www.scielo.org/

Red de Revistas Científicas de América Latina y el Caribe, España y

Portugal (RedALyC)

http://redalyc.uaemex.mx.

11 Directory of Open Access

Journals (DOAJ) http://www.doaj.org.

12 Nancy Diana Gómez, Paola

Bongiovani, "Open access and $\mathrm{A} 2 \mathrm{~K}$ :

Collaborative experiences", in Latin

American in Libraries Driving Access to Knowledge edited by Jesús Lau, Ana Maria Tammaro, and Theo D. Bothma (Munich: De Gruyter Saur, 2012), pp. 343-372, Available: doi:10.1515/9783110263121, (September 9, 2012).

Nancy Diana Gómez, Atilio

Bustos González, Julio Santillán Aldana, Olga Arias, "Open access indicators and information society". OCLC Digital libraries. 25, no. 2 (2009), pp. 82-92.

Repositories (ROAR) http://roar.eprints.org/
15

OpenDoar, The Directory of

Open Access Repositories:

http://www.opendoar.org

16 Ranking Web of Repositories:

http://repositories.webometrics.info

17 Paola Bongiovani, Silvia Nakano, "Acceso abierto en Argentina: la experiencia de articulación y coordinación institucional de los repositorios digitales en ciencia y tecnología," E-colabora, 1, no. 2 (2011), pp. 163-179.

http://publicaciones.renata.edu.co/index .php/RCEC/article/view/56, (September 9, 2012).

Argentina. Honorable Cámara de Diputados de la Nación, Proyecto de Ley 1927-D-2011 Creación de Repositorios Digitales Institucionales de Acceso Abierto, Propios o Compartidos, Online. (2011). Available: http://www1.hedn.gov.ar/proyxml/expe diente.asp? fundamentos $=$ si\&numexp $=1$ 927-D-2011, (September 9, 2012).

19 Sandra Miguel, Nancy Diana Gómez, Paola Bongiovani, “Acceso abierto real y potencial a la producción científica de un país. El caso argentino", El profesional de la información, 21, no. 2 (March-April 2012), pp. 146-153. 
$20 \quad$ Study of Open Access Publishing

(SOAPs) http://project-soap.eu/

21

Paola Bongiovani, Nancy Diana

Gómez, Sandra Miguel, “Opiniones y

hábitos de publicación en acceso abierto

de los investigadores argentinos. Un

estudio basado en los datos de la

encuesta SOAP", Revista española de

Documentación Científica, 35, no. 3

(2012), pp. 453-467. Available: doi: 10.3989/redc.2012.3.903, (September 9, 2012).

22

Siân Harris, Moving towards an open access future: the role of academic libraries, SAGE, British Library (August 2012), Available:

http://www.stm-publishing.com/whatrole-will-academic-libraries-play-inmoving-towards-an-open-accessfuture/, (September 9, 2012). 